\title{
Metacognitive Instruction: Global and Local Shifts in Considering Listening Input
}

\author{
Hossein Bozorgian $^{1}$ and Ebrahim Fakhri Alamdari ${ }^{2}$ \\ ${ }^{1}$ Queensland University of Technology, Brisbane, QLD, Australia \\ ${ }^{2}$ Department of English, Qaemshahr Branch, Islamic Azad University, Qaemshahr, Iran
}

Correspondence should be addressed to Hossein Bozorgian; h.bozorgian@qut.edu.au

Received 28 January 2013; Accepted 13 April 2013

Academic Editor: Gwo-Jen Hwang

Copyright (c) 2013 H. Bozorgian and E. Fakhri Alamdari. This is an open access article distributed under the Creative Commons Attribution License, which permits unrestricted use, distribution, and reproduction in any medium, provided the original work is properly cited.

\begin{abstract}
A key shift of thinking for effective learning and teaching of listening input has been seen and organized in education locally and globally. This study has probed whether metacognitive instruction through a pedagogical cycle shifts high-intermediate students' English language learning and English as a second language (ESL) teacher's teaching focus on listening input. Twenty male Iranian students with an age range of 18 to 24 received a guided methodology including metacognitive strategies (planning, monitoring, and evaluation) for a period of three months. This study has used the strategies and probed the importance of metacognitive instruction through interviewing both the teacher and the students. The results have shown that metacognitive instruction helped both the ESL teacher's and the students' shift of thinking about teaching and learning listening input. This key shift of thinking has implications globally and locally for classroom practices of listening input.
\end{abstract}

\section{Introduction}

The purpose of this study is as to whether metacognitive instruction through a pedagogical cycle shifts highintermediate students' learning and a teacher's teaching focus on listening input. One way teachers might embrace a shift is to raise teaching issues. This issue might be as general as their impression of their current approach used in their classroom or as specific as strategies they use in the classroom to tackle learning/teaching problems. This raising issue in teaching simply helps teachers to ask whether their teaching approach is effective or there is an alternative approach to be applied in the classroom. Given such thoughts to think about the raising issue in teaching, teachers will come up with a series of responses requiring using strategies to improve their teaching listening and develop students' learning outcome. It is clear that teachers recognize a substantial shift in the way listening input is taught. Although most of the shifts have been related to the way students and teachers use listening input in the classroom, there are some metacognitive strategies increasing listening outcomes in the classroom.
Considering a shift in teaching listening input in the past 15 years for increasing listening outcomes, several studies [18] demonstrated such a move from traditional methodology to a guided methodology through metacognitive instruction. The challenge these studies have described was that there should be a moving shift locally from teaching listening input for students in the traditional methodology to a quality teaching listening input for students globally. In other words, methodology for teaching listening input should focus on the process of learning listening through receiving benefit from metacognitive instruction. The findings of these studies shifted a quality teaching listening input for students around the globe. Despite the shift in the methodology, researchers in the field should consider a few concerns if they want to help students improve listening outcome. First, researchers need to provide appropriate curriculum for teaching listening input, and the curriculum should be modified in light of students' needs. Second, researchers should use pedagogy engaging each individual student in the curriculum to be metacognitive. Finally, researchers should make sure that students would be able to monitor 
their own progress and evaluate their listening success. If we accept the shifting premises that improving listening outcome requires a set of learning factors in the classroom, we should consider: (1) classroom management, (2) metacognitive process, (3) cognitive process, (4) parental support, and (5) teacher/student social interaction [9]. While considering the quality of metacognitive instruction in listening and shifting premises to improve listening outcome, this study has focused on whether metacognitive instruction through a pedagogical cycle shifts High-intermediate students' learning and a teacher's teaching focus on listening input. Thus, the global and local issues of teaching listening input should not be disregarded.

\section{Global Issues in Teaching Listening Input}

The topics of listening texts used in the classroom vary. Teachers and curriculum developers should consider the variety of listening texts in terms of common global issues. To integrate the common global issues, teachers and curriculum developers should align them with the purpose of the classroom to develop listening outcome. Global issues and global education are the two sides of a coin. This is because educators should consider global issues if they are willing to improve global education. The term "global issue" and "global education" are hot new buzzwords in the language teaching world [10]. Global education is the process of introducing students to world issues, providing them with relevant information, and developing the skills they will need to help work towards solutions [10]. Teachers can include listening topics related to global issues (poverty, recession, or global warming) and motivate students to discuss these issues and challenge them with any potential solutions.

Developing relevant information requires students to be familiar with the content of listening texts focusing on the events taking place around the globe. Curriculum developers and teachers should be aware of the fact that students need support to challenge the global issue before they are involved in listening activities. In fact, global issues can be included in the content of listening text in the classroom on the condition that teachers inform them of the global issues and engage them in providing some personal solutions [11]. An instance in point is a diary report data collected and analysed by Goh [12] which showed that Chinese students revealed their beliefs and knowledge of second language learning. Most of the students had the following common aspects of listening in second language learning: (i) students have an active role in their listening outcome, (ii) students need a substantial methodology for learning listening, and (iii) students need strategies to develop listening outcome.

Demonstrating potential issues of metacognitive instruction in listening helps second language students comprehend oral input. The global issue here is "how" and "what" metacognitive strategies should be provided for students in the classroom. Therefore, there are two main issues in teaching listening input globally in the classroom. First, teachers need to understand the benefit of the current listening methodologies provided by researchers in the field.
The next issue is that teachers should use listening topics appropriate for the students in the classroom.

Chamot [13] referred to the methodological issue of whether strategy instruction should be embedded or taught separately. In embedded strategy instruction, a teacher provides methodology guides for students through activities that require the use of a particular strategy but does not inform students that they use strategies to practise and apply them outside of the classroom. In contrast, teachers inform students of the predicted advantage of using a strategy separately and support them through explicit strategy instruction so that students would be able to apply and transfer strategies when required. Chamot [13] notes "research indicates that embedded strategy instruction does not lead to transfer but that direct instruction is linked to the maintenance of strategies over time and their transfer to new tasks" (page 499). Before transferring a strategy to other listening tasks, students should realize their listening issues. Teachers should help students figure out their listening issues through providing listening strategies so that they would be able to increase their listening outcome. Goh [14] conducted a study focusing on a cognitive perspective of L2 students' issues in a real-time listening. Using Anderson's [15] three cognitive models, perception, parsing, and utilization, Goh examined L2 listening issues, and the findings showed that L2 students reported ten issues using the three cognitive models. Five issues reported were in relation to word recognition and attention failure during perceptual processing. Other issues were linked to the inefficient use of parsing and lack of mental representations of parsed input. The results indicated that despite having similar issues between the two groups, students with low ability had more issues with low-level processing.

Returning to the appropriate topic issue, Carrier [16] conducted a study focusing on high school English language students who were required to have strong oral comprehension of academic texts. Carrier used listening texts appropriate in academics and used listening strategy instruction separately. Unfortunately, instruction in effective listening strategies is often not part of their ESL curriculum. The result of the study indicated that listening strategy instruction improved listening outcome and was useful in English language learners' academic content classes. After receiving listening strategy instruction for 15 sessions, students showed a statistically significant improvement in discrete and video listening outcomes, as well as note-taking ability. Carrier [16] suggests that listening strategy instruction should be part of the ESL curriculum. Using listening strategies is contingent on listening text. Vandergrift [17] maintained that students tended to use top-down and bottom-up processes differently to understand listening texts, and students used the former process when they used prior knowledge-topic, genre, and culture. The latter process was used when students built up units of meaning from the phoneme-level up to discourse-level features, and this process was developed through practice in word segmentation skills.

However, three issues reported by Field [18] debilitated listening outcome. These issues can be considered globally in listening in ESL classrooms. First, there is no accurate 
way in comprehending a listening input completely as there is an alternative way to understand it. Second, sometimes small points help understand a message rather than involving global points. Finally, students are encouraged to consider the product of listening to get a message across rather than considering the process of listening.

The results of the studies show that some global issues such as methodology and topics in listening affect listening outcomes. To help ESL students develop listening outcome, teachers and curriculum developers should also consider local issues in designing a lesson plan for teaching listening input.

\section{Local Issues in Teaching Listening Input}

The first local issue is that listening input is allocated inadequate consideration in the English language methodology in Iran. At the school level, listening input is not taught due to the traditional focus on reading and writing skills. At the college level, reading skill is emphasized. As a consequence, for students seeking high-stake tests, for example, IELTS, institutes teach listening input within the framework of a communicative language teaching (CLT) approach [19].

The second local issue is that listening input in the curriculum is embedded in an oral comprehension teaching approach through multiple choices. Therefore, the process of explicitly teaching listening is overlooked with a strong emphasis on the post hoc assessment of the products of listening. Similar methodological issues have been described by Cross [2], Field [20], Goh [21], and Vandergrift [17] in studies of ESL teaching contexts (e.g., Japan, England, Singapore, and Canada). The risks associated with neglecting listening strategies are twofold. First, methodological focus on the linguistic and semantic features of input in recorded dialogues is not substantial to the needs of students. Second, inadequate understanding of speech is without due consideration to cognitive and metacognitive causes. Thus, students are left with unresolved difficulties in their own understandings of the subtleties of linguistic and nonlinguistic stimuli.

The third local issue is that listening activities are often used to test comprehension questions, and many students experience frustration because of failure in responding to questions. Students mostly attribute their failure in understanding listening input to their inadequate competence or the linguistic difficulty of stimulus texts. In this typical methodology, then, there is a neglect of listening strategies and students are unaware of them. In a discussion of comparable situations, Graham [5] observes that continuing difficulty in understanding listening input may lead to a sense of passivity, lack of motivation, and less effective listening.

Finally, teaching listening strategies in Iran seems to be an added difficulty imposed on teachers. This is because teachers should use strategies developed in the West and translate them into the first language (Farsi). This strategy translation helps students understand the purpose of using strategies to improve their learning in the classroom. Understanding the language delivered for strategy instruction is crucial for English as a foreign language (EFL) students at beginning and lower intermediate levels [22, 23]. However, some authorities in language institutes in Iran believe that Farsi should not be used in the classroom as it may hinder English language learning.

In sum, understanding listening input is a concern for EFL students, as they naturally have no control over listening content nor are they exposed to the language outside the classroom. Researchers such as Chang and Read [24], Graham [5], and Hasan [25] attribute listening issues to: (1) the speed of delivery of the listening text, (2) lack of exposure to fluent natural speech, and (3) new registers and lexicon. The above discussion has identified the local issue in teaching listening input in the EFL context (Iran). It has also argued that the current methodology in listening neglects the process of metacognitive instruction through a pedagogical cycle. Therefore, this study has considered whether metacognitive instruction through a pedagogical cycle shifts highintermediate students' learning and a teacher's teaching focus on listening input.

\section{Metacognition and Pedagogical Cycle}

Flavell [26] first introduced the concept of "metacognition" and referred to both the knowledge about one's own cognitive processes (i.e., metacognitive knowledge) and monitoring these processes (i.e., metacognitive strategies). Metacognitive knowledge concerns knowledge about the interplay between person characteristics, task characteristics, and the available strategies in a learning situation [27], whereas metacognitive strategies (i.e., executive strategies) concern the monitoring activities actually being performed by a student in order to structure the problem-solving process.

Pedagogical cycle was defined:

Pedagogical cycle develops both top-down and
bottom-up dimensions of listening as well as
metacognitive awareness of the cognitive processes
underlying successful L2 listening. Through an
orchestrated use of hypothesis formation and ver-
ification, with the judicious application of prior
knowledge to compensate for gaps in understand-
ing, students acquire knowledge about listening
processes [17, Page 198].

\section{Methodology}

5.1. Participants. The sample consisted of 20 Iranian male university students between the ages of 18 and 24 enrolled in High-intermediate (approximately IELTS 6) and a teacher teaching in an English language institute. The teacher was 32 years old with a master's degree and 10 years of English language teaching experience. The researcher invited both the teacher and the students and began the process of this study after receiving the participants' approval.

5.2. Research Question. Does metacognitive instruction through a pedagogical cycle shift high-intermediate students' learning and a teacher's teaching focus on listening input? 
5.3. Preparation and Procedure for Conducting Metacognitive Instruction. The researcher designed and provided a lesson plan comprising ten weeks (see Table 1) to assist the teacher in understanding the purpose of the present study. Conducting the metacognitive instruction for the present study required a preparation phase contributing to the participants. The training included the lesson plan and advising the teacher on how to use it through the pedagogical cycle. The listening materials (topics/texts) for the lesson plan were based on high-intermediate level textbook focusing on daily conversation, and public speech. Furthermore, the teacher was advised how to mitigate any external variables (e.g., strict adherence to devote enough time and training) as part of the lesson plan. The lesson plan was written in alignment with the high-intermediate textbook listening in the English language institute. The preparation phase was completed two weeks before the commencement of conducting the lesson plan.

The lesson plan for metacognitive instruction consisted of four stages and spanned 70 minutes. Mostly following Vandergrift's $[17,28]$ pedagogical cycle and Vandergrift and Goh's [29] suggestions, this present study conducted a tenweek metacognitive instruction embedded in the textbook subject matter to ensure connectivity. This connectivity helped sustain training to ensure metacognitive strategies were maintained [30]. Table 1 has five columns. Column one has ten weeks in a row. Column two (first verification stage) focuses on unpacking metacognitive strategies, which helps students benefit from using them. This stage assists students in brainstorming the topics in the brackets and helps them predict the possible words they may hear. After the first-time listening, students check out their predictions and add more information to their notes. Then, they share their notes with their peers to verify their detailed knowledge of listening topic. Column three (second verification stage) is to practise metacognitive strategy through the classroom listening activities. After the second listening, students monitor their understanding of the listening topic and increase their understanding of detailed knowledge of listening text. Column four (third verification stage) is about clarifying the objective of metacognitive strategy and missing points in the listening text. After the third listening, students selectively intend to chase the information missed in previous stages. Column five (teacher's reflective stage) involves teacher's log, which has three subcolumns: (i) issues the teacher and students encountered during metacognitive instruction, (ii) teacher's suggestion, particularly on any encountered issue, and (iii) researcher's recommendations on encountered issues.

5.4. Data Collection. To assess the research question, the researcher collected qualitative data through 20 student and teacher interviews. Interviews were conducted after acting out the metacognitive instruction. The purpose of the interviews was to detail on whether metacognitive instruction through a pedagogical cycle shifted high-intermediate students' learning and a teacher's teaching focus on listening. Kvale [31] defines an interview, "an interchange of views between two or more people on a topic of mutual interest, sees the centrality of human interaction for knowledge production, and emphasises the social situatedness of research data" (page 14). An interview elicits information from spoken and unspoken angles. Cohen et al. [32] maintain that a research tool like an interview is pliable and helps a researcher derive data from a variety of channels, including verbal, nonverbal, spoken, and aural channels. This study used three structured interview questions for both students and the teacher. Pseudonyms were used for analysing the data and reporting the results.

Interviewing the students and the teacher helped the researcher to explore in depth information about the metacognitive strategies (planning, monitoring, and evaluation). All students were encouraged to use metacognitive strategies mainly in listening. Interviews with each student took between 20 minutes for one-to-one exchange of ideas in the same classroom. Three questions were whether metacognitive instruction: (1) helps you further understand, (2) assists in using planning, monitoring, and evaluation, and (3) helps you use any metacognitive strategy frequently in approaching listening input.

In order to examine whether metacognitive instruction shifts teacher's focus on teaching listening input, the researcher invited the teacher to attend a one-to-one structured interview. The foci of the teacher interview were multiple: (1) the teacher's impression during metacognitive instruction, (2) the frequency of metacognitive strategies in the classroom, and (3) issues encountered during metacognitive instruction. The researcher-teacher interview took 30 minutes and happened a week after the student interviews. Both student and teacher interviews were conducted in English language, audio-recorded, and transcribed by the researchers.

5.5. Data Analysis. Assessing the research question required analysing the student and teacher interviews. Following Cohen et al. [32] suggestions, the researcher analysed the interview transcripts, then transcribed and coded the student cohort's responses and read them to find out any potential thematic categories (e.g., [33]). In this relation, analysis of the transcribed interviews yields further evidence of reported increase in the use of metacognitive strategies in listening, from the students' own words. The students' detailed responses to all interview questions varied. For instance, some students provided more information than required, though the researcher tried to probe when needed. Interviewing the students and the teacher helped the researcher consider the different metacognitive strategies students used during listening.

When students were asked to comment on the effect of metacognitive instruction on listening outcome, almost all students agreed that metacognitive strategies should be taught explicitly in the classroom. For example, Sor attributed the metacognitive instruction in the classroom and underscored the value of metacognitive instruction, which brings about further self-confidence:

If teachers teach us metacognitive strategies, I mean strategy helps you find out this ability and 
TABLE 1: Lesson plan in metacognitive instruction.

\begin{tabular}{|c|c|c|c|c|c|c|}
\hline \multirow[b]{3}{*}{ Weeks } & \multirow[b]{3}{*}{$\begin{array}{l}\text { (1) Unpacking } \\
\text { metacognitive } \\
\text { strategy-a } \\
\text { simplified } \\
\text { definition (first } \\
\text { verification) }\end{array}$} & \multirow[b]{3}{*}{$\begin{array}{l}\text { (2) Practise } \\
\text { strategies through } \\
\text { the classroom } \\
\text { listening activities } \\
\text { (second verification) }\end{array}$} & \multicolumn{3}{|c|}{ Stages } & \multirow[b]{3}{*}{$\begin{array}{l}\text { Researcher's } \\
\text { recommendation } \\
\text { on the encountered } \\
\text { issue }\end{array}$} \\
\hline & & & (3) Emphasizing & \multicolumn{2}{|c|}{ (4) Reflection (teacher's log) } & \\
\hline & & & $\begin{array}{l}\text { metacognitive } \\
\text { strategy use and } \\
\text { missing points in } \\
\text { listening (final } \\
\text { verification) }\end{array}$ & $\begin{array}{l}\text { Issues the teacher } \\
\text { encountered } \\
\text { during } \\
\text { metacognitive } \\
\text { instruction }\end{array}$ & $\begin{array}{l}\text { Teacher's } \\
\text { suggestion, } \\
\text { particularly on the } \\
\text { encountered issue }\end{array}$ & \\
\hline 1 & $\begin{array}{l}\text { Planning } \\
\text { (going on a trip) }\end{array}$ & $\begin{array}{l}\text { Planning to "make } \\
\text { cookies for a trip" }\end{array}$ & $\begin{array}{l}\text { Highlighting the } \\
\text { purpose of } \\
\text { planning and } \\
\text { reiterating } \\
\text { available } \\
\text { information }\end{array}$ & $\begin{array}{l}\text { Students were } \\
\text { confused with the } \\
\text { metacognitive } \\
\text { strategy definition }\end{array}$ & $\begin{array}{l}\text { Involving students } \\
\text { with the listening } \\
\text { tasks }\end{array}$ & $\begin{array}{l}\text { Use a simplified } \\
\text { definition and } \\
\text { emphasize the } \\
\text { purpose of } \\
\text { metacognitive } \\
\text { strategies in } \\
\text { learning }\end{array}$ \\
\hline 2 & $\begin{array}{l}\text { Directed attention } \\
\text { (gift giving) }\end{array}$ & $\begin{array}{l}\text { "Choosing a gift for } \\
\text { his wife" - why and } \\
\text { what kind of gift } \\
\text { given to a wife }\end{array}$ & $\begin{array}{l}\text { Emphasizing } \\
\text { associative learning } \\
\text { and linkage } \\
\text { information }\end{array}$ & $\begin{array}{l}\text { Some students } \\
\text { were in doubt } \\
\text { while others } \\
\text { appreciated }\end{array}$ & $\begin{array}{l}\text { Lack of students' } \\
\text { familiarity with the } \\
\text { concepts-need } \\
\text { more emphasis on } \\
\text { the importance of } \\
\text { metacognition }\end{array}$ & $\begin{array}{l}\text { Increase students' } \\
\text { metacognitive } \\
\text { awareness }\end{array}$ \\
\hline 3 & $\begin{array}{l}\text { Selective attention } \\
\text { (having a party) }\end{array}$ & $\begin{array}{l}\text { "Party"-encourage } \\
\text { students to focus on } \\
\text { the words related to } \\
\text { the topic }\end{array}$ & $\begin{array}{l}\text { Help students find } \\
\text { key words and } \\
\text { activate their } \\
\text { existing knowledge }\end{array}$ & $\begin{array}{l}\text { Little issue with } \\
\text { key words } \\
\text { identification }\end{array}$ & $\begin{array}{l}\text { Help students } \\
\text { distinguish } \\
\text { between content } \\
\text { and function words }\end{array}$ & $\begin{array}{l}\text { Students might not } \\
\text { know which words } \\
\text { carry on the bulk } \\
\text { of meaning }\end{array}$ \\
\hline 4 & $\begin{array}{l}\text { Self-management } \\
\text { (nice weather!) }\end{array}$ & $\begin{array}{l}\text { "Weather } \\
\text { advisory"-working } \\
\text { in pairs/group to } \\
\text { increase confidence } \\
\text { in listening }\end{array}$ & $\begin{array}{l}\text { Increasing } \\
\text { students' } \\
\text { knowledge of this } \\
\text { strategy }\end{array}$ & $\begin{array}{l}\text { Trying to manage } \\
\text { their learning }\end{array}$ & $\begin{array}{l}\text { Essential to brush } \\
\text { up on the } \\
\text { metacognitive } \\
\text { concepts }\end{array}$ & $\begin{array}{l}\text { Helpful for } \\
\text { students to be } \\
\text { briefed on the } \\
\text { concepts taught } \\
\text { previously }\end{array}$ \\
\hline 5 & $\begin{array}{l}\text { Monitoring and } \\
\text { comprehension } \\
\text { monitoring (health } \\
\text { issues) }\end{array}$ & $\begin{array}{l}\text { "Headache } \\
\text { clinic"-involve } \\
\text { students with } \\
\text { potential advice } \\
\text { received in a similar } \\
\text { situation }\end{array}$ & $\begin{array}{l}\text { Increasing } \\
\text { comprehension } \\
\text { through } \\
\text { monitoring oral } \\
\text { input }\end{array}$ & $\begin{array}{l}\text { Some students } \\
\text { complain about the } \\
\text { speed of oral input } \\
\text { and little time to } \\
\text { monitor }\end{array}$ & $\begin{array}{l}\text { Help students on } \\
\text { how to } \\
\text { monitor-does not } \\
\text { need to monitor all } \\
\text { input }\end{array}$ & $\begin{array}{l}\text { Provide students } \\
\text { with some } \\
\text { instances and help } \\
\text { them practise } \\
\text { monitoring } \\
\text { strategy }\end{array}$ \\
\hline 6 & $\begin{array}{l}\text { Auditory } \\
\text { monitoring } \\
\text { (friends series) }\end{array}$ & $\begin{array}{l}\text { "Script from a TV } \\
\text { series"-engage } \\
\text { students in finding } \\
\text { sounds similar to } \\
\text { their first language }\end{array}$ & $\begin{array}{l}\text { Reiterate the } \\
\text { significance of this } \\
\text { strategy to improve } \\
\text { their listening } \\
\text { outcome }\end{array}$ & $\begin{array}{l}\text { Problems with } \\
\text { vowels in } \\
\text { English-short and } \\
\text { long vowels, for } \\
\text { example, "sun" and } \\
\text { "son" }\end{array}$ & $\begin{array}{l}\text { Provide some } \\
\text { remedial materials } \\
\text { to cope with vowel } \\
\text { problem better }\end{array}$ & $\begin{array}{l}\text { Help students } \\
\text { know some vowels } \\
\text { that are in their } \\
\text { first language but } \\
\text { not in the target } \\
\text { language }\end{array}$ \\
\hline 7 & $\begin{array}{l}\text { Double checking } \\
\text { (job hunting) }\end{array}$ & $\begin{array}{l}\text { "A job interview in } \\
\text { the United } \\
\text { States"-check out } \\
\text { their comprehension } \\
\text { in pairs/groups }\end{array}$ & $\begin{array}{l}\text { Emphasize the } \\
\text { importance of this } \\
\text { strategy and } \\
\text { increase the } \\
\text { accuracy of their } \\
\text { understanding }\end{array}$ & $\begin{array}{l}\text { Most students in } \\
\text { doubt of their } \\
\text { comprehension for } \\
\text { the first time }\end{array}$ & $\begin{array}{l}\text { More practise with } \\
\text { word identification } \\
\text { because it has more } \\
\text { effect on the } \\
\text { double checking }\end{array}$ & $\begin{array}{l}\text { Intentionally ask } \\
\text { students to } \\
\text { underline key } \\
\text { words in their } \\
\text { classroom activities } \\
\text { to highlight the } \\
\text { importance of } \\
\text { double checking }\end{array}$ \\
\hline 8 & $\begin{array}{l}\text { Evaluation } \\
\text { (call from a bank) }\end{array}$ & $\begin{array}{l}\text { "Telephone } \\
\text { conversation"- } \\
\text { students check out } \\
\text { their understandings } \\
\text { at the end of the } \\
\text { conversation to see } \\
\text { how close they were }\end{array}$ & $\begin{array}{l}\text { Reiterate the power } \\
\text { of evaluating their } \\
\text { listening outcome }\end{array}$ & $\begin{array}{l}\text { Challenging for } \\
\text { some students to } \\
\text { use in their } \\
\text { listening }\end{array}$ & $\begin{array}{l}\text { The more they } \\
\text { practise the more } \\
\text { promising their use } \\
\text { of evaluation } \\
\text { would be }\end{array}$ & $\begin{array}{l}\text { Needs more } \\
\text { practice of } \\
\text { monitoring their } \\
\text { use of evaluation in } \\
\text { the classroom }\end{array}$ \\
\hline
\end{tabular}


TABle 1: Continued.

\begin{tabular}{|c|c|c|c|c|c|c|}
\hline \multirow[b]{3}{*}{ Weeks } & \multicolumn{6}{|c|}{ Stages } \\
\hline & \multirow[b]{2}{*}{$\begin{array}{l}\text { (1) Unpacking } \\
\text { metacognitive } \\
\text { strategy-a } \\
\text { simplified } \\
\text { definition (first } \\
\text { verification) }\end{array}$} & \multirow[b]{2}{*}{$\begin{array}{l}\text { (2) Practise } \\
\text { strategies through } \\
\text { the classroom } \\
\text { listening activities } \\
\text { (second verification) }\end{array}$} & \multirow[b]{2}{*}{$\begin{array}{l}\text { (3) Emphasizing } \\
\text { metacognitive } \\
\text { strategy use and } \\
\text { missing points in } \\
\text { listening (final } \\
\text { verification) }\end{array}$} & \multicolumn{3}{|c|}{ (4) Reflection (teacher's log) } \\
\hline & & & & $\begin{array}{l}\text { Issues the teacher } \\
\text { encountered } \\
\text { during } \\
\text { metacognitive } \\
\text { instruction }\end{array}$ & $\begin{array}{l}\text { Teacher's } \\
\text { suggestion, } \\
\text { particularly on the } \\
\text { encountered issue }\end{array}$ & $\begin{array}{l}\text { Researcher's } \\
\text { recommendation } \\
\text { on the encountered } \\
\text { issue }\end{array}$ \\
\hline 9 & $\begin{array}{l}\text { Strategy evaluation } \\
\text { (family talks) }\end{array}$ & $\begin{array}{l}\text { "Conversation } \\
\text { between Kenny and } \\
\text { her mom"-using } \\
\text { strategy before and } \\
\text { during listening }\end{array}$ & $\begin{array}{l}\text { Emphasize strategy } \\
\text { evaluation and use } \\
\text { it when needed }\end{array}$ & $\begin{array}{l}\text { A few students } \\
\text { were unsure of } \\
\text { their progress and } \\
\text { were less confident } \\
\text { in using strategy } \\
\text { evaluation }\end{array}$ & $\begin{array}{l}\text { Told my students } \\
\text { mastery of } \\
\text { metacognitive } \\
\text { strategy use takes } \\
\text { some time and } \\
\text { practice }\end{array}$ & $\begin{array}{l}\text { The purpose is to } \\
\text { help them be aware } \\
\text { of metacognitive } \\
\text { strategies used in } \\
\text { listening }\end{array}$ \\
\hline 10 & $\begin{array}{l}\text { Problem } \\
\text { identification } \\
\text { (tips for writing) }\end{array}$ & $\begin{array}{l}\text { "Speech on a writing } \\
\text { assignment"-help } \\
\text { students identify } \\
\text { where they lack } \\
\text { understanding }\end{array}$ & $\begin{array}{l}\text { Providing enough } \\
\text { practice to identify } \\
\text { understanding } \\
\text { problems }\end{array}$ & $\begin{array}{l}\text { A few students got } \\
\text { less motivated as } \\
\text { they consider too } \\
\text { much of their } \\
\text { problems }\end{array}$ & $\begin{array}{l}\text { Try to motivate } \\
\text { them through } \\
\text { providing further } \\
\text { exercises }\end{array}$ & $\begin{array}{l}\text { Students need } \\
\text { more care while } \\
\text { learning new } \\
\text { learning stuff }\end{array}$ \\
\hline
\end{tabular}

use them so the main thing is in you. You have the ability and you use these strategies in improving listening. (Sor, page 1)

The teacher emphasised that students initially were not familiar with metacognitive strategies but became familiar with them at the later stage of the training and the teacher said:

\section{When I started to teach them what metacognitive strategies were, I found them pretty interested in the tasks so at the end of the study everyone came to me and appreciated me for the training throughout the course. 5 to $10 \%$ of the students used metacognitive strategies. (T., p. 15)}

Increased ability to regulate their comprehension, which was significantly influenced by one's listening ability, allowed students to better concentrate and stay on task. One student puts his metacognitive strategies used in listening as follows:

First of all to plan and if you do not plan, you do not know what to do in listening. During the listening I try to monitor and keep track of listening and not to lose my concentration because planning is very important. (Sor, page 1)

The teacher believed that students' challenges varied in terms of using metacognitive strategies in the classroom, and motivation for learning English might be a main factor. However, students acknowledged the metacognitive instruction and realised that they should actively participate in the listening input and the teacher said:

At the beginning, students were somehow confused, I mean over what I was talking about because they were familiar with the concept a little bit. When I went deep into metacognitive strategies, I found them quite interested. (T., page 16)
Students reported the frequency of metacognitive strategy use in listening: planning (60\%), monitoring (25\%), and evaluation (5\%). Whilst students were asked what metacognitive strategies they used, one of the students reported using selective attention (keyword tracking) while listening. One student, Amir (p. 4), stated that he did not use any especial metacognitive strategies, and while listening, he only considered keywords during listening.

The next student also stated that he used selective attention and keyword tracking. For example:

First, I have a plan to read the questions to find out the keywords. Then I keep these keywords in mind to follow the listening input. It helps me get to the right answers. (Meh, page 6)

When students were asked how they approached the listening input in the final exam, they mostly pointed out to a few listening strategies, such as selective attention, keyword tracking, and note-taking. For example,

I try to pay attention to the content of listening stuff and concentrate on the keywords and take a note to help me follow the discussion in the listening. (Ali, page 3)

Similarly, the teacher maintained that students were already familiar with planning and monitoring strategies but did not know how to use them strategically. They had no idea what an evaluation strategy entailed and might have thought that evaluation was a part of teacher's responsibility, as teachers normally gave students multiple tests (quizzes, midterms, and finals). The teacher stated:

Students were somehow familiar with planning, but they did not know what planning was but actually somehow they did it. Some of them were familiar with monitoring actually by taking notes and trying to review the materials, concentrating the tasks in order to find out their problems, but 
nobody was familiar with evaluation. They did not know what evaluation was. $(T ., 16,17)$

Almost all of the students came to realize that they should use metacognitive strategies in listening to regulate the role of the pedagogical cycle approach. However, half of the number of students reported that they checked out the comprehension questions during listening. Although the importance of using metacognitive strategies was dominant in terms of considering the process of listening into account, it was very hard to alter their deep-seated belief in checking out comprehension questions, which is the product of listening input. The reasons might be the following.

(1) Lack of sufficient chance to maintain the consistency of metacognitive strategies in future.

(2) Teachers of upper-level students might not pay attention to listening process approach in the classroom.

(3) Curriculum space focusing on the product of listening can be a major factor for students not regulating the process of listening.

\section{Discussion and Conclusions}

This study examined whether metacognitive instruction through pedagogical cycle shifts high-intermediate students' learning and a teacher's teaching focus on listening input. Overall, both the teacher and students demonstrated considerable changes in teaching and learning listening input through the lesson plan-a guided methodology. The very nature of listening input means that listening input fades away soon after students listen and students, therefore, thought they were not able to keep track of such input. As they were instructed with the metacognitive instruction, they realised that they could handle listening input more effectively through the pedagogical cycle. Similar to the findings of Goh [12] and Graham [5], the findings revealed that teachers can support students to regulate listening input through metacognitive instruction. To provide students with a guided methodology in the classroom, teachers assist students in dealing with difficulty of listening tasks, and speed of listening input.

This study presented similar findings as the previous research on the impact of metacognitive instruction on shifting students' views of using listening strategies $[2,4,8]$. The current study was limited in terms of identifying a shift in teaching and learning listening input through a pedagogical cycle. Despite receiving a guided methodology in listening, some students reported that they have considered the product of listening through checking out the comprehension questions. This notion is in alignment with Field [18], suggesting that encouraging students to consider the product of listening distorts the comprehension, and this orientation of listening product is a global issue. Coupled with the global issues in teaching and learning listening input, teachers should consider local issues and devote adequate time in the curriculum space and encourage students to approach listening input strategically. To approach listening strategically in this present study, teachers taught the students metacognitive strategies, and both students and the teacher acknowledged the effect of a guided methodology. This finding supports Chang and Read [24] and Hasan [25] suggesting that students can deal with the speed of listening input, exposing of natural speech, and new registers through strategy instruction.

Previous research highlights the issue of an embedded or separated methodology used for strategy instruction [13]. This present study used the embedded methodology and connected metacognitive instruction to the classroom textbook listening activities. This connectivity helped students function and transfer strategies to new tasks and assisted them in using metacognitive strategies purposefully. Both the teacher and students should embrace the notion of metacognitive instruction to approach listening input and make a plan to discuss the listening message. This peer or group discussion about listening input increased the students' understanding and the teacher's control of listening tasks taught in the classroom.

The findings of this study might serve to spotlight possible suggestions for teaching listening input in the classroom worldwide. As established by previous research $[1,2,17,21]$, the complexity of teaching listening locally and globally should not be underestimated; rather, it should be stressed, in particular locally by teachers. Curriculum developers should put sufficient time to promote the importance of teaching strategies in listening in the classroom. Future research might focus on the quantitative aspects of listening tests and metacognitive questionnaires. The reason for this shift of methodology is to measure the impact of metacognitive instruction on students' listening outcome as well as metacognitive awareness of listening process. Furthermore, it would be worthwhile to measure teachers' belief in using metacognition in listening through a questionnaire.

In conclusion, this study showed that high-intermediate students and the teacher became more aware of an alternative way of learning and teaching listening input through experiencing the metacognitive instruction. The finding indicated that enough time and the lesson plan through a pedagogical cycle used in this study transformed both the teacher's and students' views of teaching and learning listening input. Despite metacognitive instruction, a few students stuck to their traditional way of checking out comprehension questions (product) in understanding listening input. Certainly, students gradually shift their traditional focus on learning listening input to strategic way of learning it once they benefit from learning through receiving metacognitive instruction in listening. Identifying the global and local issues in teaching and learning listening input serves to enhance the learning outcome of this basic skill in second and foreign languages.

\section{References}

[1] H. Bozorgian, "Metacognitive instruction does improve listening comprehension," ISRN Education, vol. 2012, Article ID 734085, 6 pages, 2012.

[2] J. Cross, "Metacognitive instruction for helping less-skilled students," English Language Teachers Journal, vol. 65, no. 4, pp. 408-416, 2011. 
[3] J. Field, "Skills and strategies: towards a new methodology for listening," English Language Teachers Journal, vol. 52, no. 2, p. 110, 1998.

[4] C. Goh and Y. Taib, "Metacognitive instruction in listening for young learners," English Language Teachers Journal, vol. 60, no. 3, pp. 222-232, 2006.

[5] S. Graham, "Listening comprehension: the learners' perspective," System, vol. 34, no. 2, pp. 165-182, 2006.

[6] T. Lynch, "Theoretical perspectives on listening," Annual Review of Applied Linguistics, vol. 18, pp. 3-19, 1998.

[7] D. Mendelsohn, "Listening comprehension: we've come a long way, but...," Contact, vol. 27, pp. 33-40, 2001.

[8] L. Vandergrift and M. H. Tafaghodtari, "Teaching L2 learners how to listen does make a difference: an empirical study," Language Learning, vol. 60, no. 2, pp. 470-497, 2010.

[9] M. C. Wang, G. D. Haertel, and H. J. Walberg, "What helps students learn?” Educational Leadership, vol. 51, pp. 74-79, 1994.

[10] J. Provo, Teaching World Issues, Daily Yomiuri Newspaper, Tokyo, Japan, 1993.

[11] A. C. Kip, "Teaching for a better world: Global issues and language education," Human Rights Education in Asian Schools, pp. 41-52, 2005.

[12] C. Goh, "Metacognitive awareness and second language students," English Language Teachers Journal, vol. 51, pp. 361-369, 1997.

[13] A. U. Chamot, "Cognitive instruction in the second language classroom," in Linguistics, Language Teaching and Language Acquisition: The Interdependence of Theory, Practice and Research, J. E. Alatis, Ed., pp. 496-513, Georgetown University Press, Washington, DC, USA, 1990.

[14] C. Goh, "A cognitive perspective on language learners' listening comprehension problems," System, vol. 28, no. 1, pp. 55-75, 2000.

[15] J. R. Anderson, Cognitive Psychology and Its Implications, Freeman, New York, NY, USA, 4th edition, 1995.

[16] K. Carrier, "Improving high school English language learners' second language listening through strategy instruction," Bilingual Research Journal, vol. 27, no. 3, pp. 383-408, 2003.

[17] L. Vandergrift, "Recent development in second and foreign language listening comprehension research," Language Teaching, vol. 40, pp. 191-210, 2007.

[18] J. Field, "Promoting perception: lexical segmentation in second language listening," English Language Teachers Journal, vol. 57, pp. 325-334, 2003.

[19] Iran Language Institute, "Internet + English = Netglish," 2009, http://www.ili.ir/ .

[20] J. Field, “Guest editor's introduction Emergent and divergent: a view of second language listening research," System, vol. 36, no. 1, pp. 2-9, 2008.

[21] C. Goh, "Metacognitive instruction for second language listening development: theory, practice and research implications," RELC Journal, vol. 39, no. 2, pp. 188-213, 2008.

[22] H. Bozorgian and H. Pillay, "Enhancing foreign language learning through listening strategy delivered in L1: an experimental study," International Journal of Instruction, vol. 6, pp. 105-122, 2013.

[23] E. Macaro, Learning Strategies in Second and Foreign Language Classrooms, Continuum, London, UK, 2001.

[24] A. C. S. Chang and J. Read, "The effects of listening support on the listening performance of EFL learners," TESOL Quarterly, vol. 40, no. 2, pp. 375-397, 2006.
[25] A. S. Hasan, "Learners' perceptions of listening comprehension problems," Language, Culture and Curriculum, vol. 13, no. 2, pp. 137-153, 2000.

[26] J. H. Flavell, "Metacognitive aspects of problem solving," in The Nature of Intelligence, L. B. Resnick, Ed., pp. 231-236, Erlbaum, Hillsdale, NJ, USA, 1976.

[27] J. H. Flavell, "Metacognition and cognitive monitoring: a new area of cognitive-developmental inquiry," American Psychologist, vol. 34, no. 10, pp. 906-911, 1979.

[28] L. Vandergrift, "Listening to learn or learning to listen?" Annual Review of Applied Linguistics, vol. 24, pp. 3-25, 2004.

[29] L. Vandergrift and C. Goh, Teaching and Learning Second Language Listening: Metacognition in Action, Tylor \& Frances Group. New York, NY, USA; Rutledge, Oxon, UK, 2012.

[30] M. V. J. Veenman, B. H. A. M. van Hout-Wolters, and P. Afflerbach, "Metacognition and learning: conceptual and methodological considerations," Metacognition and Learning, vol. 1, no. 1, pp. 3-14, 2006.

[31] S. Kvale, Interviews, Sage, London, UK, 1996.

[32] L. Cohen, L. Manion, and K. Morrison, Research Methods in Education, Routledge, London, UK, 6th edition, 2007.

[33] V. Braun and V. Clarke, "Using thematic analysis in psychology," Qualitative Research in Psychology, vol. 3, no. 2, pp. 77-101, 2006. 

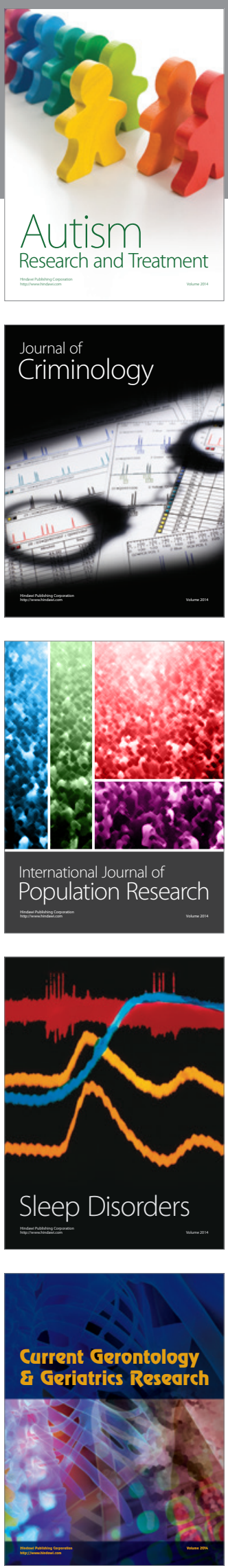
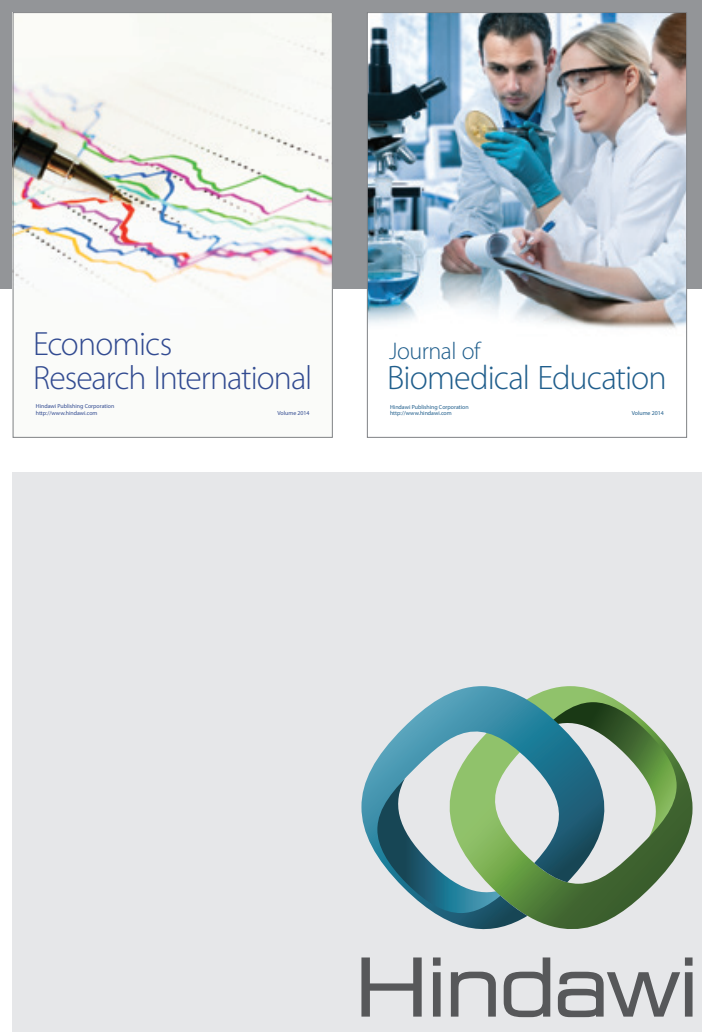

Submit your manuscripts at

http://www.hindawi.com
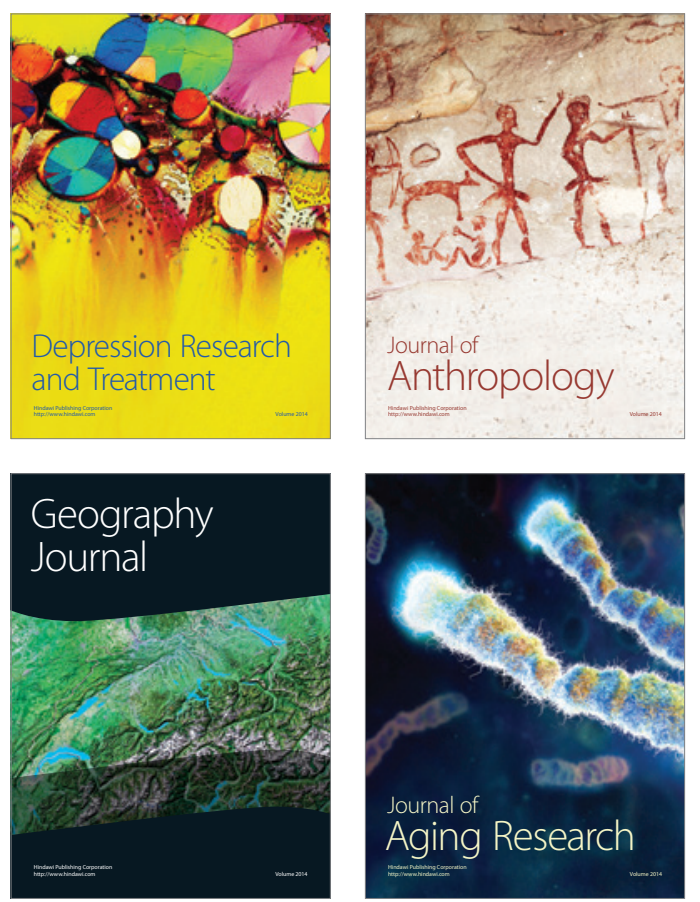
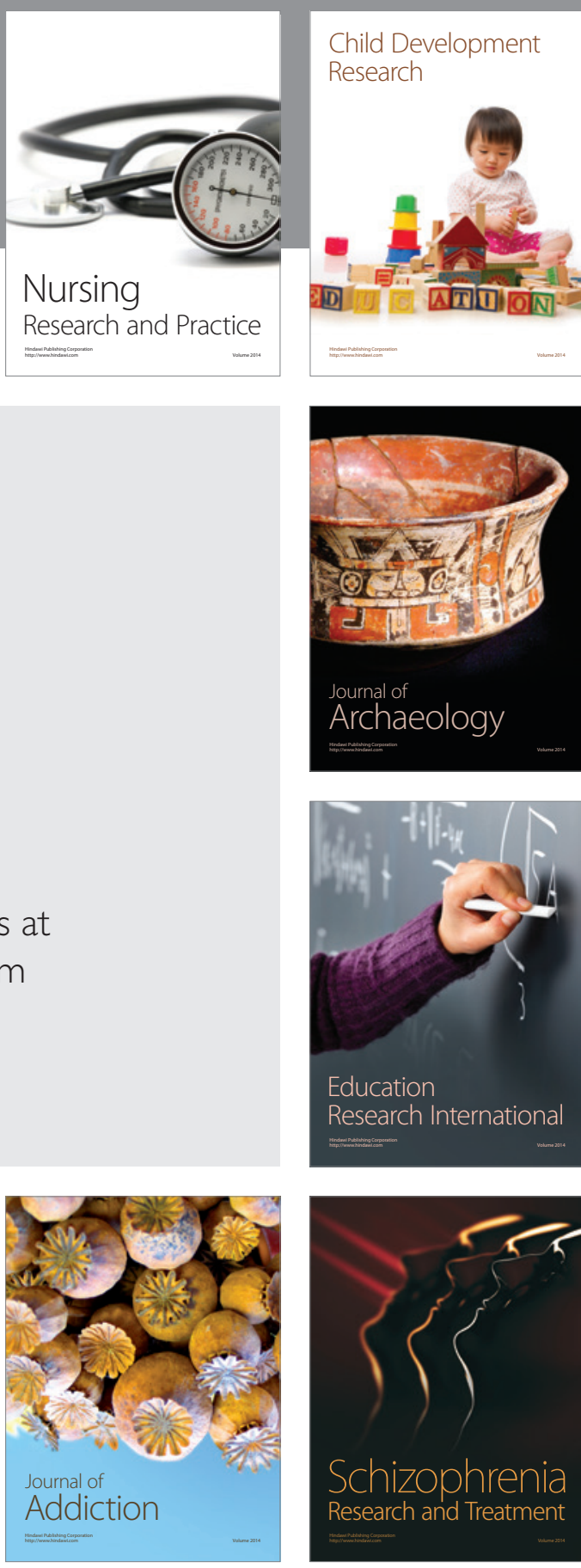

(D)
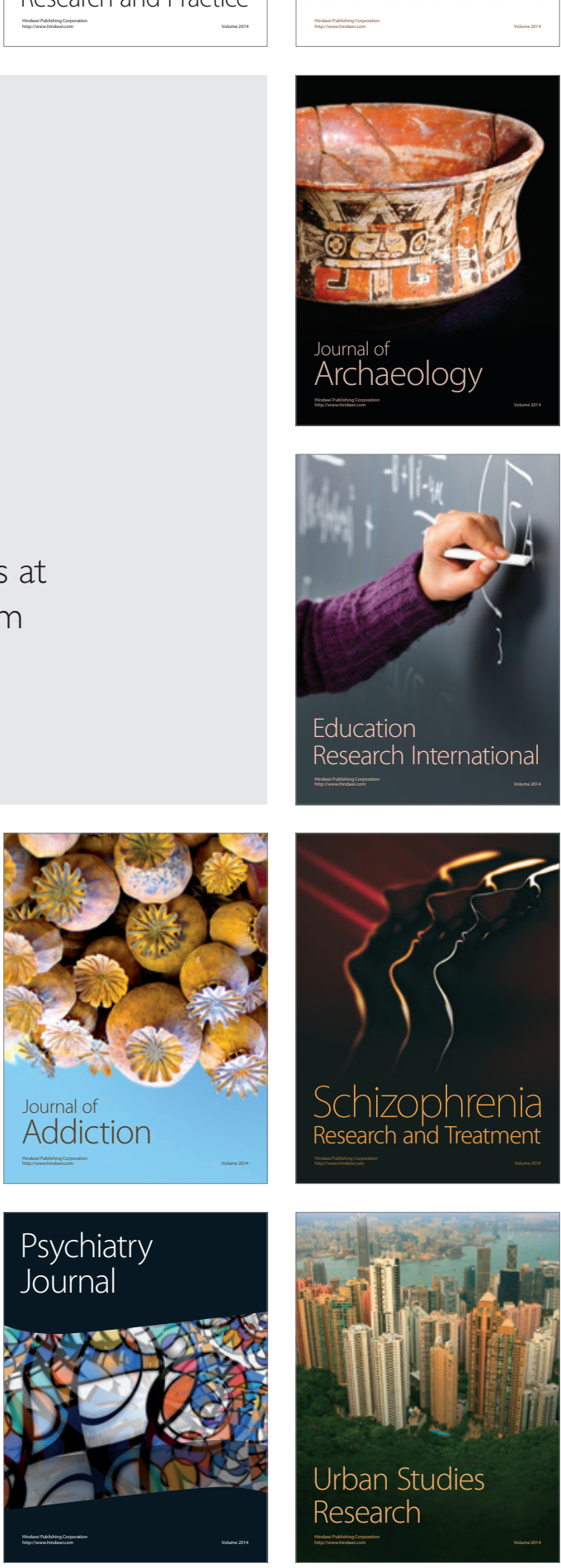